\title{
DEMOGRAPHIC FACTORS AND LABOR TURNOVER IN HONDA MANUFACTURING LIMITED OTA, OGUN STATE NIGERIA
}

\author{
Bashiru Akande Bello \\ Bells University of Technology, Ota, Nigeria \\ Patrick Ologbenla \\ Obafemi Awolowo University, Ile-Ife Nigeria \\ Onyekachi Funmilayo Okenesi \\ Bells University of Technology, Ota, Nigeria
}

\begin{abstract}
This study examines the effect of demographic factors on labor turnover in Honda Manufacturing Company. The study examines three objectives which are to determine the effect of age on labor turnover, ascertain the influence of work experience on labor turnover and determine the effect of educational qualification on labor turnover. The study attempts to provide answers to the questions to what extent does age affect labor turnover? How does work experience influence labor turnover? and to what extent does educational qualification affect labor turnover. Primary data was used in this study and the study adopted a descriptive research design. 150 questionnaires as obtained by Slovenes formula were administered to the staffs of Honda Manufacturing Limited. In analyzing this questionnaire, data analytical procedure and frequency and \%ages were used as descriptive statistics. Inferential statistics of correlation and regression analysis was used to test the hypotheses in the study. The findings of this study established that there is a significant effect of age on labor turnover in Honda Manufacturing Limited, Ota, Ogun State. The findings also indicate there is a significant relationship between educational qualification and labor turnover.
\end{abstract}

Keywords: turnover, demographic, human Resources, employee, organization.

\section{INTRODUCTION}

Employees are the heart and soul of any organisation. The aim of every organisation is to maximize their profit which is directly or indirectly related to the productivity of employees. This is because most companies need to retain, at every point in time, an efficient work force to drive the operational activities of the organization (Akinyomi, 2016). Multiple synergies come from this approach including increased on-thejob productivity of current staff, trust among existing employees which tend to make processes more efficient, reduced cost of training new staff, among others. Hence, it is critical for all organisations to strive to retain an efficient number of employees (Akinyomi, 2016). 
Employees are central to all the organisational activities. The overall goal achievement of any organisation directly depends on the collective efforts of its employees. Organizations are ready to bear the cost of acquiring the right person fit for the job. Thus, organisations invest a lot in terms of getting the right person who perfectly matches its strategic goal and culture.

For any organization to run successfully, several human elements are essential. One is good leadership that starts from the top geared towards best results; another is good organizational and management practices. Also, there must be a team of people with the knowledge, skills, aptitudes, and attitudes to perform a sufficiently high level of production to accomplish the organization mission and financial performance (Hermann, 1999).

Labor turnover is defined as the influx and exit of individuals into and out of the work force of an organization over a specific period of time. Exit from an organization can take the form of resigning, redundancy, retirement, dismissal or death. Labour turnover is widely studied with multiple perspectives and suggested various factors are the causes of turnover of employees in an organization. Labour turnover is interlinked with two main factors -demographic factors and employee satisfaction (biographic factors). Demographic factors include tenure, educational qualification, age, gender marital status, and work experience, just to mention a few. Biographic factors include financial rewards, work environment, promotion, feeling of employee self- accomplishment and self-recognition, over stress of employees, among others (Chowdhury, 2015).

\section{STATEMENT OF THE RESEARCH PROBLEM}

The impact of labour turnover has received considerable attention by senior management, human resources professionals and industrial psychologists. A high staff turnover rate has negative effect on the organization whichever way one looks at it. According to studies that have been conducted by various authors, namely Beam, (2009), Sekuguchi, (2004), who identified that one of the common reasons why employees leave is the existence of a poor relationship between the employee and his or her immediate manager. There is a saying that "people leave managers, not organizations" many employees decide to resign from an organization as a result of conflict they may be having with their immediate managers. Several other factors account for high level of labour turnover in an organisation. A group of such of factors are demographic characteristics of employees, the level of education, work experience, age and gender are also important determinants of an employee's choice to remain in or leave an organisation. These demographic variables influence people's values, wants and needs and make them think and behave differently (Monte, 2010). 
The discussion on labour turnover and demographic factors has remained a reoccurring issue in management literature. Nonetheless, these studies have shortcomings that this current study seeks to improve upon. There is no unanimous result on the impact of age on labour turnover, Swaminathan and Ananth (2009), Jans and Lenney (2010) and Hayes (2015) have different opinion on the relevance of age on employee's job satisfaction and performance. More so, the subject matter has been poorly investigated in the Nigerian context. Few studies such as Oladipo et al. (2017) which provide empirical insight on labour turnover and demographic factor in Nigeria, did not provide deep insight on the subject matter. Rather, job satisfaction has remained a major measure of labour tumover and thereby ignoring other measures of labour turnover. In addition, empirical studies in Nigeria on the subject matter, labour turnover and demographic factors focus on age, sex and education. However, this study makes use of three demographic factors, which are, age, work experience and educational qualification. Subsequently, this study seeks to improve on existing literature by exploring three measures of labour turnover (job satisfaction, employee commitment and employee compensation) and three demographic factors (age, work experience and educational qualification) towards revisiting the subject matter in Nigeria.

\section{LITERATURE REVIEW}

Bello (2018) emphasized that labour turnover plays a crucial role in an organisation's long-term achievements and success because the more workers contend, the more the low ratio of employee's turnover. This typically results in a motivated set of employees willing to collectively drive towards the targets and objectives which the organisation has set - resulting in higher yields to the organisation.

Higher level of labour turnover is detrimental to organizational performance and profitability because of its associated loss of valuable resources and human capital assets (Grissom et al., 2012; Kim, 2012). Performance and profitability are fundamental factors in organizational performance; therefore, it is strongly beneficial for organizational leaders to understand factors that have a significant potential to predict turnover, and to affect the performance of an organization (Iverson and Zatzick, 2011). Several researchers found associations between an employee's age, education, gender, income, or length of tenure with turnover intentions, as well as antecedents to turnover (Heavey et al., 2013; Shuck et al., 2011).

Agyeman (2014) examined the influence of employee demographic characteristics and their effect on turnover and retention. This study makes an attempt to analyse the various employee demographic characteristics and their effects on turnover and retention in Micro, small and medium enterprises (MSMEs). Descriptive research approach has been followed and data was collected from 120 MSMEs randomly selected from the cotton textile, agro, jute and leather-based sectors in Kancheepuram District 
through a structured questionnaire. The study also revealed that Human Resource practices are the most important and valuable means that influence employee retention in any organization, hence increasing job satisfaction, providing good working environment and career development opportunities, increasing recognition and rewards and improving communications are some of the strategies that can help minimize the turnover rate. This study suggests that retention could be enhanced with strategies or interventions. Turnover rate should be continuously monitored and given much importance in strategy formulation because turnover of talented employees constitutes the loss of a valued employee and costs such as recruitment, training and general administration are incurred that subsequently hinders growth and success of an organisation, MSMEs should recognize the importance of employees because its success also depends on its team of committed and productive employees working with it.

Hayes (2015) examined the impact of demographic characteristics predicting employee turnover intentions. A quantitative, correlational design and multiple linear regression analysis were used to examine the extent and nature of the relationship between the age, education, gender, income, and length of tenure and between turnover variables. The results of this research demonstrated a statistically significant relationship existed between an employee's age, income and turnover intention. A statistically significant relationship did not exist between an employee's education, gender or, length of tenure and turnover intention. According to this study, age has a significant relationship on labour turnover. The result of this study indicated that younger employees are more likely to have turnover intentions than older employees. Young employees' changes job on an average of 18 months and are not willing to make personal sacrifice for a job. However, the older ones are loyal employees that are willing to sacrifice their personal needs for the betterment of the organisation. This study revealed that young employees are likely to leave an organisation when they feel there is no opportunity for promotion or increase in pay within the organisation. It revealed that there is a weak relationship between income and turnover intentions. In order to retain top employees, human resource practitioners need to evaluate their salary increase and wage allocation. Increase in salary reduces turnover intentions, when employees are fairly compensated, they are less likely to seek employment outside the organisation.

Swaminathan and Ananth (2009) analysed the impact of demographic factors on employee engagement, with reference to Vasan Publications Private Limited, Chennai. The researcher adopted descriptive research and the data is collected from the employee through convenience sampling method with the help of personally administrated questionnaire containing close ended questions and the sample size is 50 . This data was analysed and classified with the help of statistical tools and the findings and suggestion are extracted from the same. Findings obtained reveal that there is no relationship between employees' experience and their improvement in the level of problem solving. More so, there is a relationship between experience and their level of satisfaction about the working hours set by the management. It was also 
found that there is no relationship between educational qualification and involvement level of the employees. Lastly, it was found that there is no significant difference exists among the employees towards the satisfaction about training programme with respect to their experience.

Khan (2013) examined the factors affecting employee turnover in an organisation. The hypotheses were tested using correlation and regression analyses. This research was conducted with the objective to find the relationship between retirement benefits, job security and financial crises and with the intention to see its impact on the employee turnover in an organization and to examine the contribution and effect of demographic variables on turnover intentions. The correlation analysis of retirement benefits and job security on turnover intentions indicated positive and significant relationship. This indicated that retirement benefits and job security are directly related to turnover intentions. The results also implied that the retirement benefits and job security of task significance, autonomy and feedback tend to decrease if employees experience high level turnover intentions. The finding also suggests that when employees perceive their organizations as having greater concern on their retirement benefits and aspects of job security the emotion of employees will be more positive.

Chowdhury (2015) examined demographic factors impacting employee turnover in the private banking sector of Bangladesh. For this purpose, information from primary and secondary sources was collected. Initially, a pilot study involving human resource managers of top banks was conducted. Based on their outputs, a close ended questionnaire was prepared and distributed to the various tiers of management officials in different banks. Quantitative analyses were done using Statistical Package for Social Science (SPSS) version 16. The reliability of the items present was estimated using Cronbach Alpha. The factors that showed greater consistency were chosen for analysis. At first, the study sought to find the relation between turnover and the demographic variables. To decipher this relationship a bivariate analysis was conducted. The factors showing significant relationship are identified and later used for hypothesis testing and model development. From this analysis, it was concluded that age, educational qualifications and tenure i.e. the number of years in an organization are the factors impacting turnover. This turnover frequency can be minimized by retention of efficient employees. Banks should also aim to retain efficient and higher qualified employees. So, either through better compensation packages or through increased job satisfaction measures these employees should be retained.

Yapa et al. (2014) examined the effect of demographic factors on job satisfaction of non-academic staff in universities. The study was conducted in university of Ruhuna; one of the leading national universities in Sri Lanka. The job dissatisfaction of non-academic employees was identified by doing pilot study and that was taken as research problem. This research employed deductive approach. This study involves job satisfaction as dependent variable and 9 independent variables. Questionnaire was developed as a 
research instrument to measure level of satisfaction and level of importance and measurements were done using Likert scale. The target population consisted of three main job categories of non-academic staff named technical grade, clerical grade, and labourer grade and 354 completed questionnaires were used for data analysis. Study found that civil status and age were the most significant factors affecting the job satisfaction and gender and level of education has no significant effect on job satisfaction.

Baloshi (2018) investigated the demographic factors as age, gender, education, ethnicity, experience, and position that affect the participation of employees in wellness programs. The study involves 307 participants from group of companies in Bahrain to investigate their response towards the employee wellness programs. The study used an adopted and self-constructed scale that involved demographic information of the participants along with the record of their participation in wellness programs. The results indicated that there is positive correlation between level of education and employees' position in the company while there is a negative correlation between age and years of experiences of employees in the current company.

Chirchir (2016) explored job satisfaction among primary school teachers in relation to certain demographic variables. The objective of this study was therefore to examine the influence of demographic factors on job satisfaction of teachers in public primary schools in Bomet County, Kenya. This was done by conducting a survey using a self-administered questionnaire. A total of 848 teachers in 129 primary schools participated in the study. Descriptive and Inferential statistics were used to analyse the data. The overall finding was that teachers were ambivalent on job satisfaction, meaning that they were not sure whether they are satisfied with their jobs. However, teachers were satisfied with their colleague co-teachers and happy when assigned administrative duties. Teachers were more satisfied when authority is delegated to them. It is evident that school leadership need to improve on in ways of supervision, systems of reward, ways of communication and working conditions. It was further established that there were significant differences in the level satisfaction of male and female teachers for satisfaction with administrative duties $(t=2.645)$ and satisfaction with teaching.

Odhiambo et al. (2018) carried out an empirical investigation that sought to determine the relationship between age diversity and employee performance of public universities in Western Kenya. The target population composed of four public universities and the respondents were 120 head of departments. The study adopted a mixed method design and a survey method was used to collect primary data using a questionnaire pretested for validity and reliability. Descriptive and inferential statistics were used to analyse the data. Out of the 120 questionnaires sent out, 93 questionnaires were received giving a response rate of $78 \%$. Regression and correlation analysis established a statistically significant positive relationship between age diversity and employee performance. The conclusions drawn from the study findings is that 
age diversity influence employee performance positively and majority of the employees are positive about age diversity practices in public universities.

\section{METHODOLOGY}

The study adopted descriptive survey design approach in which cross-sectional administration of primary sources of data collection method were used. The population of this study are the staff of Honda Manufacturing Limited. The number of employees that was used as the total population for this study is 240. The questionnaire was also subjected to expert opinion for content validity before it was administered. The Cronbach alpha coefficient is used to describe the internal consistency of scales, obtained from the Likert scale. A reliable scale is expected to have a Cronbach alpha score of above 0.7. The Cronbach alpha coefficient for Labour Turnover and Demographic Variables is 0.967 and 0.890 respectively hence seeing they are above 0.7 it can be concluded that the internal consistency of the scales is good, and the research instrument is reliable. Out of four hundred (150) questionnaires administered, only three hundred and twelve (136) copies questionnaires were valid, given $90.67 \%$ which were used for the analysis. Both descriptive and inferential statistics of simple and multiple regressions were used for analysis.

\section{RESULTS AND DISCUSSIONS}

\subsection{Respondents Socio-Demographic Characteristics}

TABLE 1. \% AGE DISTRIBUTION OF GENDER

\begin{tabular}{|ll|r|r|r|r|}
\hline & & Frequency & \multicolumn{1}{|c|}{ \% } & \multicolumn{1}{|c|}{ Valid \% } & \multicolumn{1}{c|}{ Cumulative \% } \\
\hline Valid & Male & 73 & 53.7 & 54.9 & 54.9 \\
& Female & 60 & 44.1 & 45.1 & 100.0 \\
& Total & 133 & 97.8 & 100.0 & \\
Missing & System & 3 & 2.2 & & \\
Total & & 136 & 100.0 & & \\
\hline
\end{tabular}

Source: Author Field Survey, 2019

The table above reveals that $53.7 \%$ of the respondents are male while $44.1 \%$ are female. This shows that most of the respondents are male which could be an insight into the recruitment policy of Honda Manufacturing Limited, Ota, Ogun State. 
Bello, B.A., Ologbenla, P., Okenesi, O.F.

DEMOGRAPHIC FACTORS AND LABOR TURNOVER IN HONDA MANUFACTURING LIMITED OTA, OGUN STATE NIGERIA

TABLE 2. \%AGE DISTRIBUTION OF HIGHEST ACADEMIC QUALIFICATION

\begin{tabular}{|ll|r|r|r|r|}
\hline & Frequency & \multicolumn{1}{|c|}{$\%$} & Valid \% & Cumulative \% \\
\hline Valid & Diploma & 3 & 2.2 & 2.2 & 2.2 \\
& BA./BEd./BSc. degree & 85 & 62.5 & 62.5 & 64.7 \\
MA./MEd./MSc degree & 42 & 30.9 & 30.9 & 95.6 \\
Others & 6 & 4.4 & 4.4 & 100.0 \\
Total & 136 & 100.0 & 100.0 & \\
\hline
\end{tabular}

Source: Author Field Survey, 2019

The table above reveals that $2.2 \%$ of the respondents have diploma as their highest academic qualification, $62.5 \%$ have B.A/Bed/BSc degree as their highest academic qualification, $30.9 \%$ have MA/Med/MSc degree as their highest academic qualification while $4.4 \%$ have other degrees as their highest academic qualification. This shows that majority of the respondents have B.A/Bed/BSc degree as their highest academic qualification.

TABLE 3. \%AGE DISTRIBUTION OF YEARS OF SERVICE

\begin{tabular}{|c|c|c|c|c|c|}
\hline & & Frequency & $\%$ & Valid \% & Cumulative \% \\
\hline \multirow[t]{5}{*}{ Valid } & Less than a year & 16 & 11.8 & 11.9 & 11.9 \\
\hline & $1-5$ years & 59 & 43.4 & 43.7 & 55.6 \\
\hline & $6-10$ years & 39 & 28.7 & 28.9 & 84.4 \\
\hline & $11-15$ years & 18 & 13.2 & 13.3 & 97.8 \\
\hline & Above 15 years & 3 & 2.2 & 2.2 & 100.0 \\
\hline Total & & 136 & 100.0 & & \\
\hline
\end{tabular}

Source: Author Field Survey, 2019

The table above reveals that $11.8 \%$ of the respondents have years of service of less than a year, 43.4 $\%$ of the respondents have years of service of between $1-5$ years, $28.7 \%$ of the respondents have years of service of between $6-10$ years, $13.2 \%$ of the respondents have years of service of between 10-15 years while $2.2 \%$ of the respondents have years of service of above 15 years. This means that most of the respondents have years of service of between 6-10 years. 
Bello, B.A., Ologbenla, P., Okenesi, O.F.

\subsection{Test of Hypotheses}

\section{Hypotheses One}

$\mathrm{H}_{0}$ : There is no significant effect of age on labor turnover in Honda Manufacturing Limited, Ota, Ogun state.

$\mathrm{H}_{1}$ : There is a significant effect of age on labor turnover in Honda Manufacturing Limited, Ota, Ogun state.

TABLE 4. MODEL SUMMARY

\begin{tabular}{|l|r|r|r|r|}
\hline Model & $\mathrm{R}$ & R Square & $\begin{array}{c}\text { Adjusted R } \\
\text { Square }\end{array}$ & $\begin{array}{c}\text { Std. Error of } \\
\text { the Estimate }\end{array}$ \\
\hline 1 & $.781(\mathrm{a})$ & .611 & .608 & .80136 \\
\hline
\end{tabular}

a Predictors: (Constant), Age

Source: Author's Computation, 2019

The model summary statistics shows the level of relationship between independent variable and the dependent variables. The table shows that the $\mathrm{R}^{2}=0.611$ which shows that $61.1 \%$ of the variance in the dependent variable (Labor Turnover) is explained by the independent variable (Age).

TABLE 5. ANOVA (B)

\begin{tabular}{|ll|r|r|r|r|r|}
\hline \multicolumn{1}{|l|}{ Model } & \multicolumn{1}{c|}{$\begin{array}{c}\text { Sum of } \\
\text { Squares }\end{array}$} & Df & Mean Square & F & \multicolumn{1}{c|}{ Sig. } \\
\hline 1 & Regression & 134.978 & 1 & 134.978 & 210.187 & $.000(\mathrm{a})$ \\
& Residual & 86.052 & 134 & .642 & & \\
& Total & 221.029 & 135 & & & \\
\hline
\end{tabular}

a Predictors: (Constant), Age

b Dependent Variable: Labor Turnover

Source: Author's Computation, 2019

The F-test statistics provides the test of the overall significance of the regression model. A test of the overall significance of the model shows $(F(1,134)=210.187, p<0.05)$. This implies that the model is statistically significant and can be used to predict the response variable. 
Bello, B.A., Ologbenla, P., Okenesi, O.F.

DEMOGRAPHIC FACTORS AND LABOR TURNOVER IN HONDA MANUFACTURING LIMITED OTA, OGUN STATE NIGERIA

TABLE 6. COEFFICIENTS (A)

\begin{tabular}{|c|c|c|c|c|c|c|}
\hline \multicolumn{2}{|c|}{ Model } & \multicolumn{2}{|c|}{$\begin{array}{c}\text { Unstandardized } \\
\text { Coefficients }\end{array}$} & \multirow{2}{*}{$\begin{array}{c}\text { Standardized } \\
\text { Coefficients } \\
\text { Beta }\end{array}$} & \multirow{2}{*}{$\begin{array}{l}t \\
B\end{array}$} & \multirow{2}{*}{$\begin{array}{c}\text { Sig. } \\
\text { Std. Error }\end{array}$} \\
\hline & & B & Std. Error & & & \\
\hline \multirow[t]{2}{*}{1} & (Constant) & 5.280 & .224 & & 23.585 & .000 \\
\hline & Age & -.816 & .056 & .781 & -14.498 & .000 \\
\hline
\end{tabular}

a Dependent Variable: Labor Turnover

Source: Author's Computation, 2019

From table above, it can be seen that the beta co-efficient of Age is 0.781 which implies that $78.1 \%$ of the dependent variable (Labor Turnover) is explained by the independent variable (Age). The significant value is 0.000 , which is less than 0.05 this shows that age is making a significant contribution to the prediction of the level of Labor Turnover. Therefore, we reject the null hypothesis that says there is no significant effect of age on labor turnover in Honda Manufacturing Limited, Ota, Ogun state and accept the alternate hypothesis. Furthermore, the positive sign of the beta coefficient indicates that the higher the age of an employee base, the higher the likelihood of Labor Turnover.

\subsection{Hypotheses Two}

$\mathrm{H}_{0}$ : There is no significant relationship between work experience and labor turnover in Honda Manufacturing Limited, Ota, Ogun state.

$\mathrm{H}_{1}$ : There is a significant relationship between work experience and labor turnover in Honda Manufacturing Limited, Ota, Ogun state.

TABLE 7. CORRELATIONS

\begin{tabular}{|lll|r|r|}
\hline & & \multicolumn{1}{c|}{$\begin{array}{c}\text { Work } \\
\text { Experience }\end{array}$} & $\begin{array}{c}\text { Labor } \\
\text { Turnover }\end{array}$ \\
\hline Spearman's rho & Work Experience & Correlation Coefficient & 1.000 & $.739\left(^{* *}\right)$ \\
& & Sig. (2-tailed) &. & .000 \\
& & $\mathrm{~N}$ & 136 & 136 \\
& \multirow{3}{*}{ Labor Turnover } & Correlation Coefficient & $.739\left(^{* *}\right)$ & 1.000 \\
& & Sig. (2-tailed) & .000 &. \\
& $\mathrm{~N}$ & 136 & 136 \\
\hline
\end{tabular}

${ }^{\text {** }}$ Correlation is significant at the 0.01 level (2-tailed).

Source: Author's Computation, 2019 
The relationship between Labor Turnover and Work experience was tested using the Spearman rank correlation analysis technique. The results of the analysis showed that there is a strong significant positive correlation between work experience and labor turnover, $r=.739, n=136, p<.05(.000)$ at the $5 \%$ level of significance with work experience being positively correlated with labor turnover. Therefore, we reject the null hypothesis which states that there is no significant relationship between work experience and labor turnover in Honda Manufacturing Limited, Ota, Ogun state and accept the alternate hypothesis. The positive relationship between the two variables shows that higher the level of work experiences of an employee base, the higher the likelihood of Labor Turnover.

\subsection{Hypotheses Three}

$\mathrm{H}_{0}$ : There is no significant relationship between educational qualification and labor turnover in Honda Manufacturing Limited, Ota, Ogun state.

$\mathrm{H}_{1}$ : There is a significant relationship between educational qualification and labor turnover in Honda Manufacturing Limited, Ota, Ogun state.

TABLE 8. CORRELATIONS

\begin{tabular}{|lll|r|r|}
\hline & & $\begin{array}{r}\text { Educational } \\
\text { qualification }\end{array}$ & $\begin{array}{c}\text { Labor } \\
\text { Turnover }\end{array}$ \\
\hline Spearman's rho & Educational qualification & Correlation Coefficient & 1.000 & $\left..721{ }^{* *}\right)$ \\
& & Sig. (2-tailed) &. & .000 \\
& & $\mathrm{~N}$ & 136 & 132 \\
& \multirow{3}{*}{ Labor Turnover } & Correlation Coefficient & $.721\left(^{* *}\right)$ & 1.000 \\
& & Sig. (2-tailed) & .000 &. \\
& $\mathrm{~N}$ & 132 & 132 \\
\hline
\end{tabular}

** Correlation is significant at the 0.01 level (2-tailed)

Source: Author's Computation, 2019

The relationship between Labor Turnover and Educational Qualification was tested using the Spearman rank correlation analysis technique. The results of the analysis showed that there is a strong significant positive correlation between educational qualification and labor turnover, $r=.721, n=132, p<.05(.000)$ at the $5 \%$ level of significance with educational qualification being positively correlated with labor turnover. Therefore, we reject the null hypothesis which states that there is no significant relationship between educational qualification and labor turnover in Honda Manufacturing Limited, Ota, Ogun state and accept the alternate hypothesis. The positive relationship between the two variables shows that 
higher the level of educational qualification of an employee base, the higher the likelihood of Labor Turnover.

\section{CONCLUSIONS}

The importance of employees in ensuring organizational sustainability in a corporate entity cannot be overemphasized. However, key to organizational sustainability is also the level of labor turnover. Previous studies have shown that a high labor turnover affects an organizations' ability to produce consistently efficient and effective result, also it affects an organizations identity and reputation, and can affect its growth and sustainability. From the study, it can be seen that there are certain factors that influence the labor turnover within an organization, and they can be grouped as demographic factors. The study showed that the age of an employee, the work experience of an employee and educational qualification of an employee are significant demographic factors that influence labor turnover. Therefore, it can be concluded that there is a significant positive relationship between age, work experience and educational qualification of employees and labor turnover within an organization.

\section{RECOMMENDATIONS}

- Management of Honda Manufacturing Limited should conduct adequate human resource planning to ensure that they are able to appropriately replace ageing employees within the organization.

- Also, the management of Honda Manufacturing Limited should prepare attractive salary and compensation packages for employees and should review these packages annually to ensure that they reflect the educational qualification and work experience.

- Management of Honda Manufacturing Limited should create conducive working environments and flexible work structure that encourages employees to stay and encourages potential employees to desire working in the organization.

- The management of Honda Manufacturing Limited should also ensure that as employees increase their level of education and work experience, they are given positions that are on par with their level of education and work experience.

\section{REFERENCES}

Agyeman, C. M., \& Ponniah, V. M. (2014). Employee demographic characteristics and their effects on turnover and retention in MSMEs. International Journal of Recent Advances in Organzitional Behaviour and Decision Sciences, 1(1), 12-29. 
Akinyomi, O. J. (2016). Labor turnover: causes, consequences and prevention. Fountain University Journal of Management and Social Sciences. 5(1): $105-112$

Baloshi, M. B. (2018). Demographic Factor That Affect Employees Participation in Wellbeing Program in Bahrain. Int. J. Youth Eco. 2 (2): 145-164

Beam, J. (2009). What is employee turnover? Retrieved March 15, 2020, from http://www.wisegeek.com/what-is-employee-turnover.htm

Bello, B. A (2018). Demographic factors and organisational citizenship behavior in the wire and cable industry in south western Nigeria. Pacific journal of science and technology. 19(2): 168-179

Chirchir, R. (2016). Demographic Factors and Job Satisfaction: A Case of Teachers in Public Primary Schools in Bomet County, Kenya. Journal of Education and Practice. 7(13): 25-30

Chowdhury, F. (2015). Demographic Factors Impacting Employee Turnover in the Private Banking Sector of Bangladesh. International Journal of Business and Management Invention. 4(11): 4654

Grissom, J. A., Nicholson-Crotty, J., \& Keiser, L. (2012). Does my boss's gender matter? Explaining job satisfaction and employee turnover in the public sector. Journal of Public Administration Research and Theory, 22(4), 649-673.

Hayes, T. M. (2015). Demographic Characteristics Predicting Employee Turnover Intentions. 34(1): 97115

Heavey, A. L., Holwerda, J. A., and Hausknecht, J. P. (2013). Causes and Consequences of Collective Turnover: A Meta-analytic Review. Journal of Applied Psychology. 98(1): 412-453

Hermann, J. (1999). Job Satisfaction, Organizational Commitment, Turnover Intention, and Turnover: Path Analysis Based on Meta-analysis Findings. Personnel Psychology. 46(1): 259-293

Iverson, R. D., \& Zatzick, C. D. (2011). The effect of downsizing on labor productivity. The value of showing considerations for employee's morale and welfare in high performance at work systems. Human Resource Management. 50(1): 29-44

Jans, C. V. O., and Lenny, S. (2010). Age, Wage and Productivity. IZA Discussion Paper No. 4765

Khan, S. A. (2013). The factors affecting employee turnover in an organization: The case of Overseas Pakistanis foundation. African journal of business management. 8(1): 25-34

$\mathrm{Kim}, \mathrm{S},(2012)$. The impact of human resource management on state government IT employee turnover intentions. Public Personnel Management. 41(1): 257-279

Monte, P. A. (2010). Job Dissatisfaction and Labor Turnover: Evidence from Brazil. The International Journal of Human Resource Management. 23(8):1717-1735

Odhiambo, M. W., Gachoka, H. G., and Rambo, C. M. (2018). Relationship between Age Diversity and Employee Performance of Public Universities in Western Kenya. International Journal of Academic Research in Business and Social Sciences. 8 (11): 20-44

Oladipo, K. S., Ismi, A. B. I., Bahaman, A. S., and Adekanye, T. B. (2017). Influence of Demographic Variable on Job Satisfaction Among Academicians in Public Universities. International Journal of Innovative Business Strategies (IJIBS), 3 (1): 89-102

Sekuguchi, T. (2004). Person - Organization Fit and Person - Job Fit in Employee Selection: A review of the literature. Engineering. 54(6): 179-196

Shuck, B., Reio, T. G., and Rocco, T. S. (2011). Employee engagement: An examination of antecedent and outcome variables. Human Resource Development International. 14(1): 427-445 
Swaminathan, J., and Ananth, A. (2009). Impact of demographic factors on employee engagement- a study with reference to vasan publications private limited. Chennai. MPRA paper No. 39768.

Yapa, P.M., Rathnayake, R.M., Senanayake, G., and Premakumara, P. (2014). Effect of Demographic Factors on Job Satisfaction of Non-Academic Staff in Universities. Reshaping Management and Economic Thinking through Integrating Eco-Friendly and Ethical Practices Proceedings of the 3rd International Conference on Management and Economics 26-27 February 2014. 